\title{
Abundance and Diversity of Holothuroids in Shallow Habitats of the Northern Red Sea
}

\author{
Boaz Yuval, ${ }^{1}$ Lee Sudai, ${ }^{2}$ and Yarden $\mathrm{Ziv}^{2}$ \\ ${ }^{1}$ Interuniversity Institute for Marine Sciences Eilat and Faculty of Agriculture, Food and Environment, \\ Hebrew University of Jerusalem, P.O. Box 12, 70795 Rehovot, Israel \\ ${ }^{2}$ Department of Biology, Ben Gurion University of the Negev, Beer Sheva, Israel
}

Correspondence should be addressed to Boaz Yuval; boaz.yuval@mail.huji.ac.il

Received 11 August 2014; Revised 20 October 2014; Accepted 27 October 2014; Published 13 November 2014

Academic Editor: Evgeny Pakhomov

Copyright (C) 2014 Boaz Yuval et al. This is an open access article distributed under the Creative Commons Attribution License, which permits unrestricted use, distribution, and reproduction in any medium, provided the original work is properly cited.

\begin{abstract}
Holothuroid sea cucumbers are vital members of Coral Reefs and associated marine habitats and provide vital ecological services. In the southern regions of the Red Sea their populations have been decimated by overfishing. The main objective of this study was to test the hypothesis that the northern part of the Red Sea serves as an ecological refuge for the species threatened farther to the south. Accordingly, populations of sea cucumbers in 4 shallow sites south of Eilat, Israel $\left(29^{\circ} 33^{\prime} 00 \mathrm{~N} 34^{\circ} 57^{\prime} 14 \mathrm{E}\right)$, were repeatedly surveyed from November 2013 to April 2014. Overall 11 species were observed in these shallow sites. Their abundance and diversity differed significantly between sites, but not temporally. In sites in marine protected areas, with an intact fringing reef, diversity was high, with Holothuria edulis and Bohadschia sp. being the most common species. In areas with higher human use and characterized by rubble and scattered corals, diversity was low, and Actinopyga bannwarthi was the most common species. The observed abundance and diversity did not support the refuge hypothesis. These findings are discussed in relation to other surveys of abundance and diversity in similar habitats.
\end{abstract}

\section{Introduction}

Holothuroid sea cucumbers provide vital (and often overlooked) ecological services in the habitats they occupy. As primarily sediment feeders they effectively provide, through bioturbation and remineralization, significant amounts of otherwise inaccessible nutrients to other organisms in the benthic environment [1-7]. In addition, many species of this group have commercial value and are exploited in fisheries, often in an unregulated manner with severe ecological consequences [8-10]. Furthermore, these animals contain untold numbers of bioactive molecules, of potential applications for human nutrition and health (e.g., [11]). In order to understand the ecological services provided by these animals, to plan and regulate fisheries in a sustainable manner, and eventually to mine their unknown molecular bounty, a basic knowledge of their community structure is needed, followed by an analysis of the forces that shape and maintain this structure.

Historically, distributions of species were catalogued in area wide taxonomic surveys, thus providing a firm basis for future work [12-14]. Subsequently, patterns of sea cucumber diversity and abundance have been determined for many locations in the world, particularly for areas where fisheries are an important source of local revenue (reviewed in [9]; e.g., [15-17]). Concurrently, information about holothuroid community structure in many areas of the Indian Ocean and Africa, both associated with fisheries and not, is emerging (e.g., [18-21]).

In general, holothuroids are more abundant and diverse in complex habitats, but the scaling of samples is important in such analyses, with greater variability at finer spatial scales [22]. Why particular species and species assemblages are found in different habitats has been addressed in several studies and largely attributed to differences in diet, size, developmental stage, organic content, habitat complexity, and physical characteristics of substrate. In addition, exposure to oceanic waves can be a major determinant of local abundance and diversity [15]. For example, focusing on distribution of sea cucumbers in the various habitats surrounding the island 


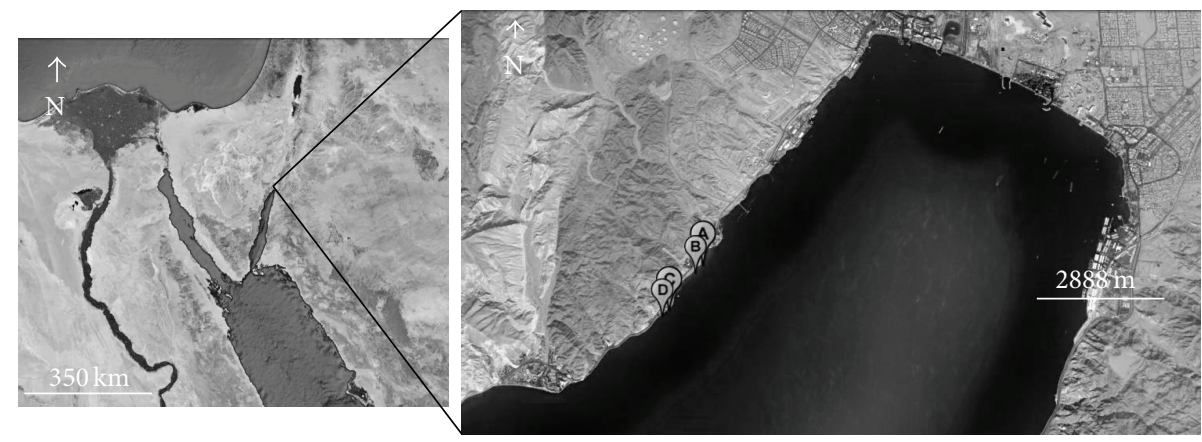

FIGURE 1: Study area south of Eilat, Israel $\left(29^{\circ} 33^{\prime} 00 \mathrm{~N} 34^{\circ} 57^{\prime} 14 \mathrm{E}\right)$. Survey sites are (A) coral beach, (B) Japanese gardens, (C) Interuniversity Institute, and (D) Lighthouse.

of Mayotte, Eriksson et al. [20] found that although species overlap in their habitat choices, substrate was in many cases a reliable predictor of segregation. Similarly, Dissanayake and Stefansson [23] who studied the habitat preferences of Holothuria atra Jaeger and H. edulis Lesson around Sri Lanka concluded that depth and substrate significantly affect their distribution. They suggest that niche separation is fuelled by their disparate preference for sediments that differ in organic content. Interspecific difference in food or sediment preferences (or lack of them) may produce discrete spatial effects. Uthicke and Karez [24] studied in the lab how nutrients in the sediment affect patch choice in several species. They found that while members of the genus Holothuria had only a weak (or none at all) tendency to select their food source, Stichopus species were able to select a preferred sediment patch. Thus, the habitat segregation between species commonly found in most surveys probably also reflects morphological and behavioral differences in feeding and physiological differences in digestion and processing of nutrients.

The Red Sea is a hotspot of marine biodiversity [25]. Nevertheless, human activities are taking their toll, whether as a result of pollution, overfishing, or recreation (e.g., [26]). Holothuroid diversity of this region was described from a taxonomic perspective in the 20th century by several authors [12, 13, 27-29]. More recently, fisheries (both regulated and unregulated) were developed in both Egypt and Saudi Arabia, attended by research aimed at identifying and monitoring the sea cucumber populations [30-33]. These studies show that overfishing has decimated populations of commercially valuable holothuroids and suggest that they will be slow to recover (also see $[34,35]$ ). In addition to the grim insights regarding overfishing, these studies provide valuable information on the diversity and abundance of all holothuroid species in the various habitats and regions of the Red Sea [32, $33,35]$. The gulf of Aqaba opens in the south into the north of the Red Sea. Its northernmost shore is shared by Egypt, Jordan, and Israel, and although serving 2 major ports and many recreational activities, it has no sea cucumber fisheries. Thus an intriguing hypothesis emerges; namely, this area may serve as an ecological refuge for the depleted populations of commercially important species in the southern regions of the Red Sea.
Support for this hypothesis is lacking, as apart from the taxonomic catalogues published in the 1970's and before (see above) the holothuroids of the Israeli and Jordanian shores of the gulf of Aqaba have never been examined in an ecological context. Accordingly, the objectives of this study were to survey the communities of holothuroids in several shallow habitats near Eilat, Israel. We determined whether diversity varied spatially and temporally between four different habitats that differed ecologically and in patterns of human disturbance.

\section{Materials and Methods}

2.1. Survey Sites. We systematically surveyed four discrete transects of coastline, each approximately 5 meters wide and between 158 and 220 meters in length. These were (1) Coral Reef, (2) Japanese Gardens, (3) Interuniversity Institute, and (4) Lighthouse (Figure 1). While the entire coast of the southern gulf of Eilat (between the town and the Egyptian border) is officially a nature reserve, sites 1 and 2 are within a fenced in reserve called "Coral Beach." In this site the fringing reef is intact, rising from a depth of $\sim 4$ meters. Beyond the reef, a sandy bottom dotted with coral outcrops slopes gently into the depths. Our site was the part of this reserve that is open to the public, who has access via bridges that span the lagoon and reach the outer fringe of the reef. The Japanese Gardens are further to the south and access to them is restricted to 2-4 boatloads of divers per day. Thus within this protected site we could test the hypothesis that intensity of human presence affects community structure of holothuroids. The next 2 sites are ecologically and structurally distinct. The first is opposite the Interuniversity Institute and exhibits a gentle slope dotted with coral colonies and patches of sand. The adjacent site (Lighthouse) is composed primarily of sand and rubble, interspersed with a few heads of coral. The Interuniversity Institute is relatively undisturbed by human activity, while the Lighthouse is a popular beach under heavy human pressure. Surveys were conducted by snorkeling along the transects on 6 occasions between November 2013 and April 2014.

As a measure of diversity we calculated the ShannonWeaver (Wiener) index (H; (38)). Diversity within and 
TABLE 1: Species of holothuroids observed and their density (extrapolated to individuals per hectare) at four shallow sites off the coast of Eilat, Red Sea.

\begin{tabular}{|c|c|c|c|c|}
\hline Species/Site & Coral Beach & Japanese Gardens & Interuniversity Institute & Lighthouse \\
\hline Actinopyga bannwarthi Panning & 61.5 & 43.2 & 293.2 & 284.8 \\
\hline Bohadschia cousteaui Cherbonnier & 41 & 60.5 & 0 & 3 \\
\hline Bohadschia tenuissima Semper & 80 & 151.3 & 23.2 & 2.8 \\
\hline Holothuria atra Jaeger & 69.7 & 23.7 & 12.7 & 12.2 \\
\hline Holothuria edulis Lesson & 151.7 & 118.9 & 4.2 & 4.5 \\
\hline Holothuria fuscogilva Cherbonnier & 4.1 & 2.1 & 2.1 & 1.5 \\
\hline Holothuria leucospilota Brandt & 26.6 & 12.9 & 14.8 & 12.2 \\
\hline Holothuria nobilis (Selenka) & 0 & 0 & 4.2 & 0 \\
\hline Stichopus hermanni Semper & 0 & 0 & 0 & 1.5 \\
\hline Stichopus horrens Selenka & 6.1 & 2.1 & 0 & 0 \\
\hline Synapta maculata Chamisso and Eysenhardt & 4.1 & 0 & 0 & 1.06 \\
\hline
\end{tabular}

between sites was analyzed by 2 way ANOVA with site and replicate as variables, using the JMP statistical package (SAS Institute, Cary, North Carolina). Relationships between habitat and community structure were examined by linear discriminant analysis.

2.2. Holothuroid Identification. Beginning in 2010, areas to be surveyed were traversed by SCUBA, and all individual sea cucumbers encountered were photographed, including dorsal and ventral aspects, as well as location and characteristics of anal openings. Subsequently, holothuroids were identified based on this visual record of their external features, relying heavily on published descriptions and keys (primarily [12, $36,37]$ ), as well as material in the collections of the Hebrew University and Tel Aviv University.

\section{Results}

Overall 814 holothuroids belonging to 11 species were observed in our surveys (Table 1). Diversity overall differed significantly (whole model $F_{8,13}=10.01 ; r^{2}=0.86 ; P=$ $0.0002)$. This result was due to a significant difference between sites $\left(F_{3}=25.2 ; P<0.0001\right)$, but not between replicates $\left(F_{5}=1.2 ; P=0.32\right)$. A post hoc $t$-test comparing the sites revealed that the IUI and Lighthouse sites differed significantly from the Coral Reef and Japanese Garden (Figure 2, $P<0.05$ ).

The dominant species in the Coral Reef and Japanese Gardens were Holothuria edulis Lesson and Bohadschia tenuissima Semper, respectively. In both the IUI and Lighthouse sites, Actinopyga bannwarthi Panning was the dominant species (Figure 3).

Using linear discriminant analysis we determined whether habitat could predict community structure (Figure 3). Of the 22 samples analyzed in this manner only one sample (from IUI) was misclassified (as belonging to the Lighthouse). All other samples were correctly identified by site. While the IUI and Lighthouse sites, dominated by A. bannwarthi, clumped together, there was a significant separation between the Coral Beach and Japanese Gardens sites (Figure 4).

In addition to the species listed in Table 1, three other species were observed in the same sites and depths, but

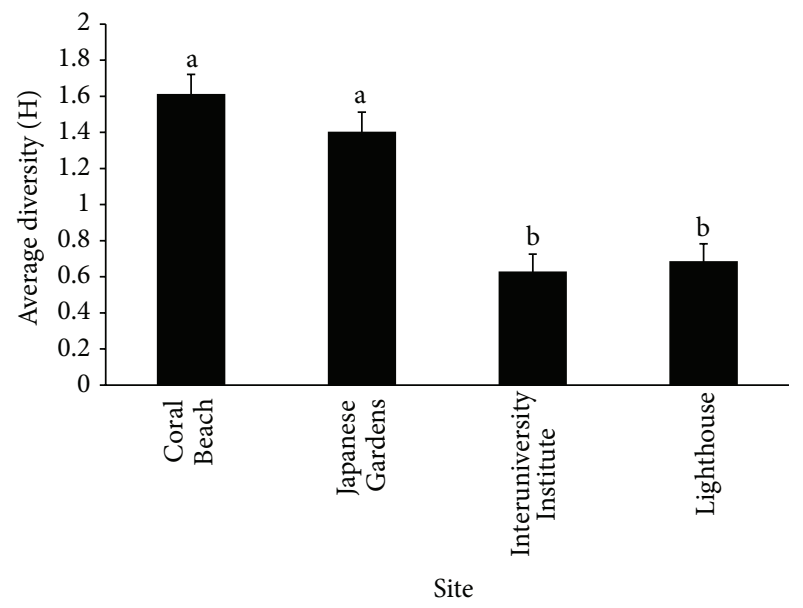

FIGURE 2: Diversity (Shannon-Weaver H $( \pm$ S.E.)) of the holothuroid community in the 4 sites sampled. Different letters denote a significant difference between sites $(P<0.05$, ANOVA followed by post hoc Student's $t$-test).

on other occasions-these are Bohadschia steinitzi Cherbonnier, Actinopyga mauritiana (Quoy and Gaimard), and Pearsonothuria graeffei (Semper). The former were seen in both the Coral Beach and Interuniversity Institute sites, the latter only in the Coral Beach site.

Although populations in deeper sites were not surveyed systematically, both the Coral Beach and IUI sites were surveyed by SCUBA on several occasions, at depths between 10-15 meters. Important to note that $A$. bannwarthi was virtually absent at depths greater than 10 meters, and that H. nobilis (Selenka) and H. fuscogilva Cherbonnier were more common than in the shallows. Furthermore, several Stichopodid species were also seen at these depths-Stichopus horrens Selenka and S. chloronotus Brandt.

\section{Discussion}

In our survey of shallow habitats we found robust communities composed of at least 11 sea cucumber species. 

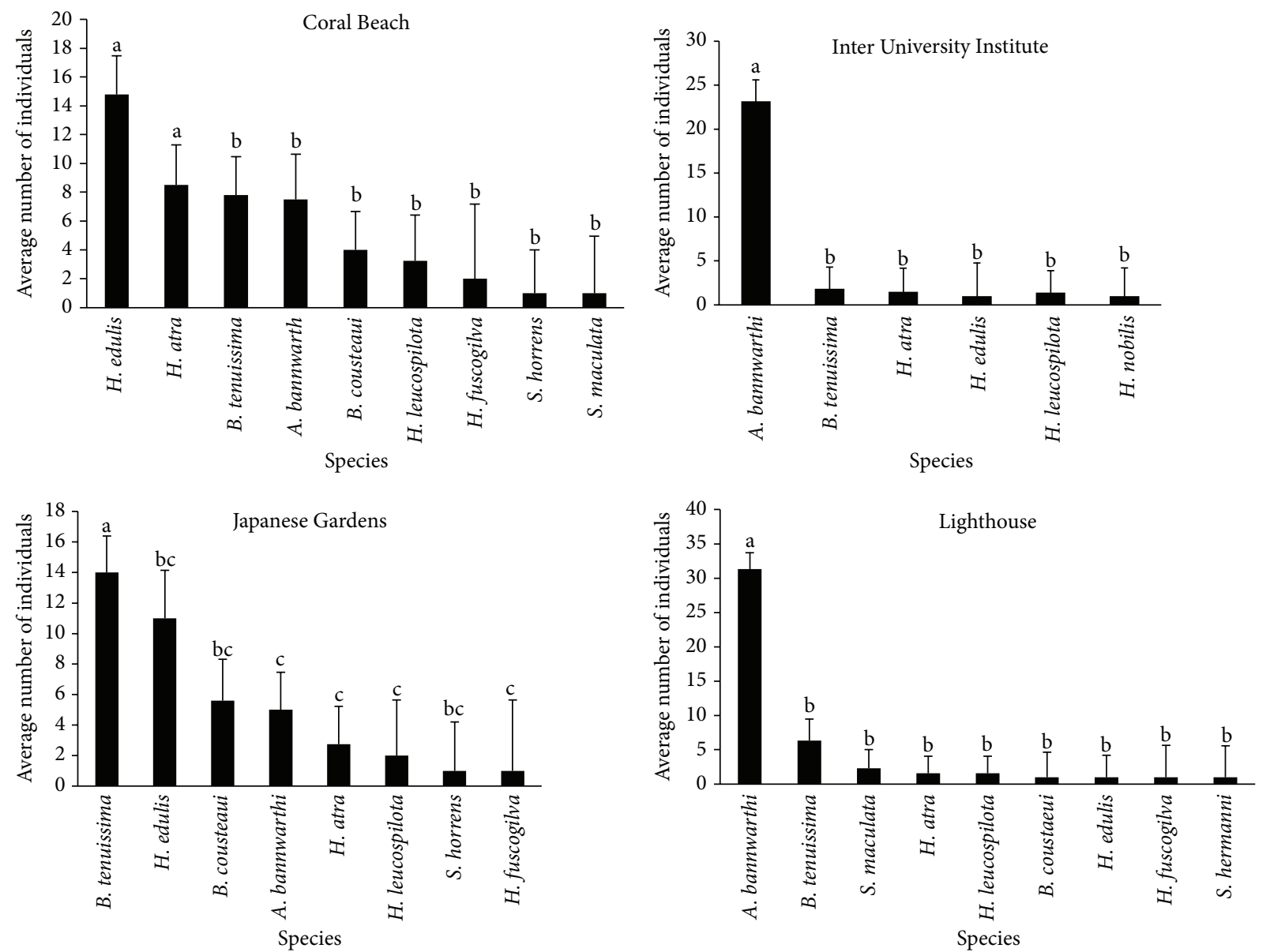

Figure 3: Abundance of holothuroids in the 4 sites sampled. Data averaged ( \pm S.E.) from 5-6 replicates per site. Different letters denote significant differences in abundance between species within sites $(P<0.05$, ANOVA followed by post hoc Student's $t$-test).

The structure of these communities did not differ temporally but showed a significant habitat effect. This finding is consistent with other studies conducted in Indian Ocean and African coastal sites, yet it also has unique features. The main habitat related difference we observed is evident when comparing the pair of Coral Beach and Japanese Garden sites to the IUI and Lighthouse. In the former, diversity is significantly higher, and the dominant species are $H$. edulis and $B$. tenuissima. In the latter, diversity is lower, and $A$. bannwarthi is the dominant species. To what may this difference be attributed? There is an obvious physical difference between the paired sites. In the Coral BeachJapanese Gardens pair, surveys were done over the sandy bottom, bordering the outer side of the fringing reef. The IUI and Lighthouse habitats are characterized by coral rubble and patches of living coral. This seems to be the main physical difference between the sites.

Another intriguing difference is that found between the communities in the Coral Beach and the Japanese Gardens. Both these sites are spatially contiguous and have similar physical characteristics. There is however one striking difference-human pressure. Access to the Japanese Gardens is strictly forbidden from the shore, and only a few boatloads of divers are allowed each day. These divers are mostly active at greater depths than were surveyed. Thus it is possible that the emergence of a Bohadschia dominated community in the Japanese Gardens reflects their sensitivity to human activity, prevalent in the Coral Beach site. Conversely, it may be that H. edulis, which dominated in the Coral Beach transects, has a specific adaptation that promotes their abundance in this habitat.

The most curious finding is the local dominance of $A$. bannwarthi, an otherwise rare and rather obscure species [38-40], in the IUI and Lighthouse sites. In a previous study the local abundance of this species in sea grass habitats near the seaport of Eilat was attributed to its ability to deal with high levels of phosphate pollution [41]. Our study shows that it is locally abundant in the relatively more disturbed habitats we surveyed. These are not contiguous with the seaport area, suggesting that other factors, beyond phosphate pollution radiating out from the port, determine the abundance of this species. South of Eilat, this species is rare [35, 41]. Thus, the reasons for the overall limited distribution of this species and very patchy local abundance around Eilat are as yet unexplained. 


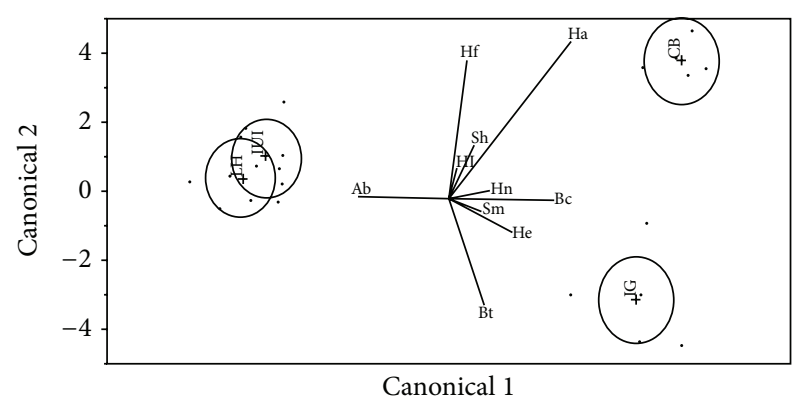

FIGURE 4: Discriminant analysis of holothuroid abundance by sampling site. This canonical plot shows the points and multivariate means in the two dimensions that best separate the groups. Labeled circles represent multivariate means for each site sampled. The size of the circles corresponds to a 95\% confidence limit for the mean. Groups that are significantly different have nonintersecting circles. Labeled rays emanating from the grand mean show the directions of the variables (species) in the canonical space. $\mathrm{CB}$-Coral Beach; JG-Japanese Gardens; IUI-Interuniversity Institute; LH-Lighthouse. Ab-Actinopyga bannwarthi; $\mathrm{Bc}-$ Bohadschia cousteaui; $\mathrm{Bt}-$ B. tenuissima; $\mathrm{Ha}-$ Holothuria atra; $\mathrm{He}-\mathrm{H}$. edulis; $\mathrm{Hf}-\mathrm{H}$. fuscogilva; $\mathrm{Hl}-\mathrm{H}$. leucospilota; Hn-H. nobilis; Sm-Synapta maculata; Sh-Stichopus horrens.

Our observed densities of $H$. atra Jaeger were, depending on the site, between 70 and 12 individuals per hectare. In Saudi Arabia the density of $H$. atra was generally low (2040 individuals per hectare), except for one site (Gadeefa), where populations in a sandy habitat reached 460 per hectare [32]. In one area of the Great Barrier Reef [42] and in Guam [15], H. atra was more abundant by an order of magnitude than that of the population we surveyed. In yet other areas of the Great Barrier Reef densities were similar to those we observed [6]. Similarly, in the western Indian Ocean island of Mayotte, $\mathrm{H}$. atra was found at a density of close to 50 individuals per hectare [20]. Around Reunion both $H$. atra and $H$. leucospilota Brandt were superabundant at some sites (6000 and 1000 individuals per hectare, resp.), but quite patchy overall [19]. These unusual densities were attributed to high local levels of eutrophication.

Holothuria edulis was highly abundant in our 2 fringing reef sites (151-118 individuals per hectare), yet it was not overabundant in the other Red Sea habitats surveyed (1020 individuals per hectare, [32]). Dissanayake and Stefansson [23] studied the habitat preferences of $H$. atra and $H$. edulis around Sri Lanka, concluding that depth and substrate significantly affect their distribution. Both were common in shallow depths $(<10 \mathrm{~m})$, although $H$. edulis reappeared at depths greater than $25 \mathrm{~m}$. However in the sandy area close to the reef, $H$. edulis, as in our study, was clearly the dominant species. They suggest that niche separation is fuelled by their disparate preference for sediments that differ in organic content. This may reflect morphological and behavioral differences in feeding and physiological differences in digestion and processing of nutrients.

In general the local abundance of species in our surveys was similar to that reported for other localities and significantly different from others. These local differences in abundance probably reflect differences in community structure, human disturbances, and available nutrients, as well as sampling methods and effort. This suggests that the carrying capacities for each species in Coral Reef habitats are quite unique and their determinants need to be understood in a local context.

Bohadschia tenuissima and B. cousteaui Cherbonnier were very common in the Coral Beach and Japanese Gardens sites. Their identification is based primarily on the detailed descriptions of live and preserved animals provided by Cherbonnier $[12,27]$ and examining specimens in the collections of the Hebrew University and Tel Aviv University. Identifying these animals without molecular and microscopic confirmation is problematic as many species may look alike and different populations of the same species may have different phenotypes [43]. The individuals of B. tenuissima were relatively easy to identify, as they presented with a yellowish trivium and brown bivium exactly as described by Cherbonnier [12]. However individuals of B. steinitzi, an endemic species collected 60 years ago in the same area where we worked [27], were not identified by snorkeling. This animal is very similar in dorsal coloration to B. cousteaui [27], and both may have inadvertently been grouped together. In SCUBA surveys we have definitely seen this species, which can be identified by its anal papillae, overall dark coloration, and propensity to eject pinkish Cuvier tubules at the slightest provocation.

In terms of diversity, the numbers of species we found are comparable to other shallow sites in the Red Sea and Indian Ocean. Thus, for example, in 18 sites sampled offshore of Saudi Arabia, a total of twelve species were recorded [32]. Overall, while species of low commercial value seem to be hanging on (e.g., H. atra), those of high value were decimated by overfishing (ibid).

Lawrence et al. [33] observed a total of 15 species in the gulf of Aqaba and 22 in the southern areas of the Red Sea. Interestingly, several species they mention from the gulf of Aqaba did not show up in our survey-Actinopyga crassa Panning, B. vitiensis (Semper), H. hilla Lesson, H. pardalis Selenka, H. scabra Jaeger, and H. impatiens (Forsskal). Furthermore, a number of species (albeit at low densities) showed up in our surveys that were absent in this 2004 report: P. graeffi, $H$. fuscogilva, and $H$. nobilis. In a further study Lawrence et al. [35] observed 11 species in the gulf of Aqaba. Curiously, A. bannwarthi, B. tenuissima, and B. cousteaui were not recorded from this area, although the latter 2 species were frequently seen in the southern part of the Red Sea (ibid).

Around the island of Reunion Conand and Mangion [19] recorded 17 species. Some (e.g., H. atra and H. leucospilota) were very abundant at some sites, but highly patchy overall. In addition, as in other studies, the reef zone had an effect on species distributions. In a survey of nearby Mauritius, Lampe [21] found 16 species, of which an unidentified synaptid accounted for $41 \%$ of all sea cucumbers observed, while $H$. atra and $\mathrm{H}$. leucospilota combined for another $40 \%$ of all observations.

Eriksson et al. [20] used blanket Manta tows to survey the Aspidochirotida of Mayotte. Among the habitats they surveyed was the fringing reef. Of a total of 22 species 
observed, the six most common were B. atra, H. atra, H. fuscopunctata Jaeger, $H$. nobilis, and Thelenota ananas (Jaeger). These species and their local densities were associated with different substrate types. For example, $H$. atra density in the fringing reef habitat was close to 50 individuals/hectare, and B. atra Massin Rasolofonirina Conand \& Samyn, around 80, yet both were relatively rare in other habitats.

Farther afield, in Guam, Kerr et al. [15] recorded 19 species in 1993. They concluded that exposure to oceanic waves is a major determinant of abundance and diversity. This conclusion was based on the finding that the reef slopes had only 10 species, while most species were found in the middle reef flats. In their survey $H$. atra was by far the most abundant species, comprising $92 \%$ of all individuals. A reassessment of the same fauna, conducted 20 years later with high intensity sampling during day and night, with snorkeling and SCUBA, across a variety of habitats, and intensified by repeated efforts resulted in the identification of 65 species from 7 families [16].

It is well documented that overfishing causes severe declines in abundance, leading to slow recovery and even local extinctions $[9,10,17,44]$. Overfishing in both Egypt and Saudi Arabia has led to significant declines of commercially valuable species. For example, H. scabra Jaeger was once superabundant ( $\sim 80$ individuals $\left.100 \mathrm{~m}^{2}\right)$ in sandy habitats off Abu Ramada Island (southern Egypt), yet declined drastically in 1999-2003 (<1 individual $100 \mathrm{~m}^{2}$ ) as a result of overfishing [34]. Overfishing also resulted in a decline in weight and eventually cessation of spawning. Overfishing has led to the implementation of strict regulations in both Egypt and Saudi Arabia, the effect of which will take several years to become evident [31-34]. Nevertheless, there is some evidence that protected areas can help recover populations damaged by overfishing. Cariglia et al. [18] surveyed several sites around Seychelles and found that protected areas had significantly higher densities of holothuroids. We hypothesized that the relatively protected areas in the northern gulf of Aqaba may serve as ecological refugia for species overfished further to the south. Indeed, recent evidence suggests that due to the unique properties of the Red Sea, some coral species do indeed enjoy a refuge in its northern reaches [45]. Although we found relatively high densities of some species of limited commercial importance (e.g., H. edulis), the low densities of the highly valuable species (e.g., $H$. nobilis and $H$. fuscogilva) provide little support for this hypothesis. More studies, at greater depth and in diverse habitats, in addition to understanding spawning behavior and larval ecology, are needed in this context.

\section{Conflict of Interests}

The authors declare that there is no conflict of interests regarding the publication of this paper.

\section{Acknowledgments}

Helpful comments by 2 reviewers improved a previous version of this paper. The authors thank Natalie Chernihovsky, Itai Granot, Eyal Yuval, Matan Yuval, and Margareta Zarubin for help with photography and SCUBA during the preliminary stage of the study. Thanks are due to Oded BenShifrut and Genadi Zaltzman of the IUI diving center for support in all matters regarding SCUBA and the Israel Nature and Parks Authority for permission to conduct surveys.

\section{References}

[1] T. MacTavish, J. Stenton-Dozey, K. Vopel, and C. Savage, "Deposit-feeding sea cucumbers enhance mineralization and nutrient cycling in organically-enriched coastal sediments," PLoS ONE, vol. 7, no. 11, Article ID e50031, 2012.

[2] P. G. Navarro, S. García-Sanz, J. M. Barrio, and F. Tuya, "Feeding and movement patterns of the sea cucumber Holothuria sanctori," Marine Biology, vol. 160, no. 11, pp. 2957-2966, 2013.

[3] K. Schneider, J. Silverman, E. Woolsey, H. Eriksson, M. Byrne, and K. Caldeira, "Potential influence of sea cucumbers on coral reef $\mathrm{CaCO}_{3}$ budget: a case study at One Tree Reef," Journal of Geophysical Research G: Biogeosciences, vol. 116, no. 4, 2011.

[4] G. R. Shiell and B. Knott, "Aggregations and temporal changes in the activity and bioturbation contribution of the sea cucumber Holothuria whitmaei (Echinodermata: Holothuroidea)," Marine Ecology Progress Series, vol. 415, pp. 127-139, 2010.

[5] S. Uthicke, "Sediment bioturbation and impact of feeding activity of Holothuria (Halodeima) atra and Stichopus chloronotus, two sediment feeding holothurians, at Lizard Island, great barrier reef," Bulletin of Marine Science, vol. 64, no. 1, pp. 129141, 1999.

[6] S. Uthicke, "Influence of asexual reproduction on the structure and dynamics of Holothuria (Halodeima) atra and Stichopus chloronotus populations of the Great Barrier Reef," Marine and Freshwater Research, vol. 52, no. 2, pp. 205-215, 2001.

[7] S.-M. Wolkenhauer, S. Uthicke, C. Burridge, T. Skewes, and R. Pitcher, "The ecological role of Holothuria scabra (Echinodermata: Holothuroidea) within subtropical seagrass beds," Journal of the Marine Biological Association of the United Kingdom, vol. 90, no. 2, pp. 215-223, 2010.

[8] S. W. Purcell, A. Mercier, C. Conand et al., "Sea cucumber fisheries: global analysis of stocks, management measures and drivers of overfishing," Fish and Fisheries, vol. 14, no. 1, pp. 3459, 2013.

[9] V. Toral-Granda, A. Lovatelli, and Vasconcellos M, Eds., Sea Cucumbers: A Global Review of Fisheries and Trade, FAO Fisheries and Aquaculture Technical Paper 516, FAO, Rome, Italy, 2008.

[10] S. Uthicke, D. Welch, and J. A. H. Benzie, "Slow growth and lack of recovery in overfished holothurians on the Great Barrier Reef: evidence from DNA fingerprints and repeated large-scale surveys," Conservation Biology, vol. 18, no. 5, pp. 1395-1404, 2004.

[11] P. L. Kiew and M. M. Don, "Jewel of the seabed: sea cucumbers as nutritional and drug candidates," International Journal of Food Sciences and Nutrition, vol. 63, no. 5, pp. 616-636, 2012.

[12] G. Cherbonnier, "Les holothuries de la Mer Rouge," Annales de l'Institut Océanographique Monaco, vol. 30, pp. 129-183, 1955.

[13] A. M. Clark and F. W. E. Rowe, "Monograph of shallow water Indo-West Pacific echinoderms," Bulletin of the British Museum of Natural History, vol. 17, pp. 81-128, 1971.

[14] D. L. Pawson, The Echinoderm fauna of Ascension Island, South Atlantic Ocean, Smithsonian Institution Press, 1978.

[15] A. M. Kerr, E. M. Stoffel, and R. L. Yoon, "Abundance distribution of holothuroids (Echinodermata: Holothuroidea) on 
a windward and leeward fringing coral reef, Guam, Mariana Islands," Bulletin of Marine Science, vol. 52, no. 2, pp. 780-791, 1993.

[16] F. Michonneau, G. H. Borrero-Perez, M. Honey et al., “The littoral sea cucumbers (echinodermata: Holothuroidea) of guam re-assessed-a diversity curve that still does not asymptote," Cahiers de Biologie Marine, vol. 54, no. 4, pp. 531-540, 2013.

[17] S. P. Woo, Z. Yasin, S. H. Ismail, and S. H. Tan, “The distribution and diversity of sea cucumbers in the coral reefs of the South China Sea, Sulu Sea and Sulawesi Sea," Deep-Sea Research Part II: Topical Studies in Oceanography, vol. 96, pp. 13-18, 2013.

[18] N. Cariglia, S. K. Wilson, N. A. J. Graham et al., "Sea cucumbers in the Seychelles: effects of marine protected areas on highvalue species," Aquatic Conservation: Marine and Freshwater Ecosystems, vol. 23, no. 3, pp. 418-428, 2013.

[19] C. Conand and P. Mangion, "Sea cucumbers on La Reunion Island fringing reefs: Diversity, distribution, abundance and structure of the populations," SPC Beche-de-mer Information Bulletin, vol. 17, pp. 27-33, 2002.

[20] H. Eriksson, M. Byrne, and M. De La Torre-Castro, "Sea cucumber (Aspidochirotida) community, distribution and habitat utilization on the reefs of Mayotte, Western Indian Ocean," Marine Ecology Progress Series, vol. 452, pp. 159-170, 2012.

[21] K. Lampe, " Holothurian density, distribution and diversity comparing sites with different degrees of exploitation in the shallow lagoons of Mauritius," SPC Beche-de-Mer Information Bulletin, vol. 33, pp. 23-29, 2013.

[22] L. Entrambasaguas, Á. Pérez-Ruzafa, J. A. García-Charton, B. Stobart, and J. J. Bacallado, "Abundance, spatial distribution and habitat relationships of echinoderms in the Cabo Verde Archipelago (eastern Atlantic)," Marine and Freshwater Research, vol. 59, no. 6, pp. 477-488, 2008.

[23] D. C. T. Dissanayake and G. Stefansson, "Habitat preference of sea cucumbers: Holothuria atra and Holothuria edulis in the coastal waters of Sri Lanka," Journal of the Marine Biological Association of the United Kingdom, vol. 92, no. 3, pp. 581-590, 2012.

[24] S. Uthicke and R. Karez, "Sediment patch selectivity in tropical sea cucumbers (Holothurioidea: Aspidochirotida) analysed with multiple choice experiments," Journal of Experimental Marine Biology and Ecology, vol. 236, no. 1, pp. 69-87, 1999.

[25] C. M. Roberts, C. J. McClean, J. E. N. Veron et al., "Marine biodiversity hotspots and conservation priorities for tropical reefs," Science, vol. 295, no. 5558, pp. 1280-1284, 2002.

[26] A. R. G. Price, S. J. Ghazi, P. J. Tkaczynski et al., "Shifting environmental baselines in the Red Sea," Marine Pollution Bulletin, vol. 78, no. 1-2, pp. 96-101, 2014.

[27] G. Cherbonnier, "Les Holothuries de la Mer Rouge de l'Université Hébraïque de Jerusalem," Bulletin Sea Fishery Research Station Haifa, vol. 34, pp. 5-10, 1963.

[28] L. Fishelson, "Ecology and distribution of benthic fauna in shallow waters of Red Sea," Marine Biology, vol. 10, no. 2, pp. 113-133, 1971.

[29] F. D. Por, H. Steinitz, I. Ferber, and W. Aron, "Biota of Red-Sea and Eastern Mediterranean (1967-1972) a survey of marine life of Israel and surroundings," Israel Journal of Zoology, vol. 21, pp. 459-523, 1972.

[30] M. I. Ahmed and A. J. Lawrence, "The status of commercial sea cucumbers from Egypt's northern Red Sea Coast," SPC Beche de Mer Information Bulletin, vol. 26, pp. 14-18, 2007.
[31] M. H. Hassan, "isheries status and management plan for Saudi Arabian sea cucumbers," SPC Beche-de-Mer Information Bulletin, vol. 28, pp. 14-21, 2008.

[32] M. H. Hassan, "Stock assessment of holothuroid populations in the Red Sea waters of Saudi Arabia," SPC Beche de Mer Information Bulletin, vol. 29, pp. 31-37, 2009.

[33] A. J. Lawrence, M. Ahmed, M. Hanafy, H. Gabr, A. Ibrahim, and A. Gab-Alla, "Status of the sea cucumber fishery in the Red Sea-the Egyptian experience," in Advances in Sea Cucumber Aquaculture and Management, A. Lovatelli, C. Conand, S. Purcell et al., Eds., Technical paper 463, pp. 173-180, Rome Food and Agricultural Organisation, 2004.

[34] M. H. Hasan, "Destruction of a Holothuria scabra population by overfishing at Abu Rhamada Island in the Red Sea," Marine Environmental Research, vol. 60, no. 4, pp. 489-511, 2005.

[35] A. J. Lawrence, R. Afifi, M. Ahmed, S. Khalifa, and T. Paget, "Bioactivity as an options value of sea cucumbers in the Egyptian Red sea," Conservation Biology, vol. 24, no. 1, pp. 217225, 2010.

[36] C. Conand, "Holothurians," FAO Fisheries Technical Paper 272.2, Food and Agriculture Organization, Rome, Italy, 1990.

[37] S. Purcell, Y. Samyn, and C. Conand, Commercially Important Sea Cucumbers of the World, FAO, Rome, Italy, 2012.

[38] C. Conand, "Actinopyga bannwarthi," The IUCN Red List of Threatened Species, Version 2014.1, 2013, http://www.iucnredlist.org/details/180510/0.

[39] Y. Samyn, D. Vandenspiegel, and C. Massin, "A new Indo-West Pacific species of Actinopyga (Holothuroidea: Aspidochirotida: Holothuriidae)," Zootaxa, vol. 1138, pp. 53-68, 2006.

[40] A. S. Thandar, "Additions to the aspidochirotid, molpadid and apodid holothuroids (Echinodermata: Holothuroidea) from the east coast of Southern Africa, with descriptions of new species," Zootaxa, no. 1414, pp. 1-62, 2007.

[41] Y. Shlesinger, "Distribution patterns of the holothurian Actinopyga bannwarthi as correlated with levels of phosphate pollution in the gulf of Eilat (Red Sea)," in Environmental Quality and Ecosystem Stability, Z. Dubinsky and Y. Steinberger, Eds., pp. 195-203, Bar-Ilan University Press, Ramat Gan, Israel, 1986.

[42] J. Lee, M. Byrne, and S. Uthicke, "The influence of population density on fission and growth of Holothuria atra in natural mesocosms," Journal of Experimental Marine Biology and Ecology, vol. 365, no. 2, pp. 126-135, 2008.

[43] S. W. Kim, A. M. Kerr, and G. Paulay, "Colour, confusion, and crossing: resolution of species problems in Bohadschia (Echinodermata: Holothuroidea)," Zoological Journal of the Linnean Society, vol. 168, no. 1, pp. 81-97, 2013.

[44] A. R. G. Price, L. E. Evans, N. Rowlands, and J. P. Hawkins, "Negligible recovery in Chagos holothurians (sea cucumbers)," Aquatic Conservation: Marine and Freshwater Ecosystems, vol. 23, no. 6, pp. 811-819, 2013.

[45] M. Fine, H. Gildor, and A. Genin, "A coral reef refuge in the Red Sea," Global Change Biology, vol. 19, no. 12, pp. 3640-3647, 2013. 

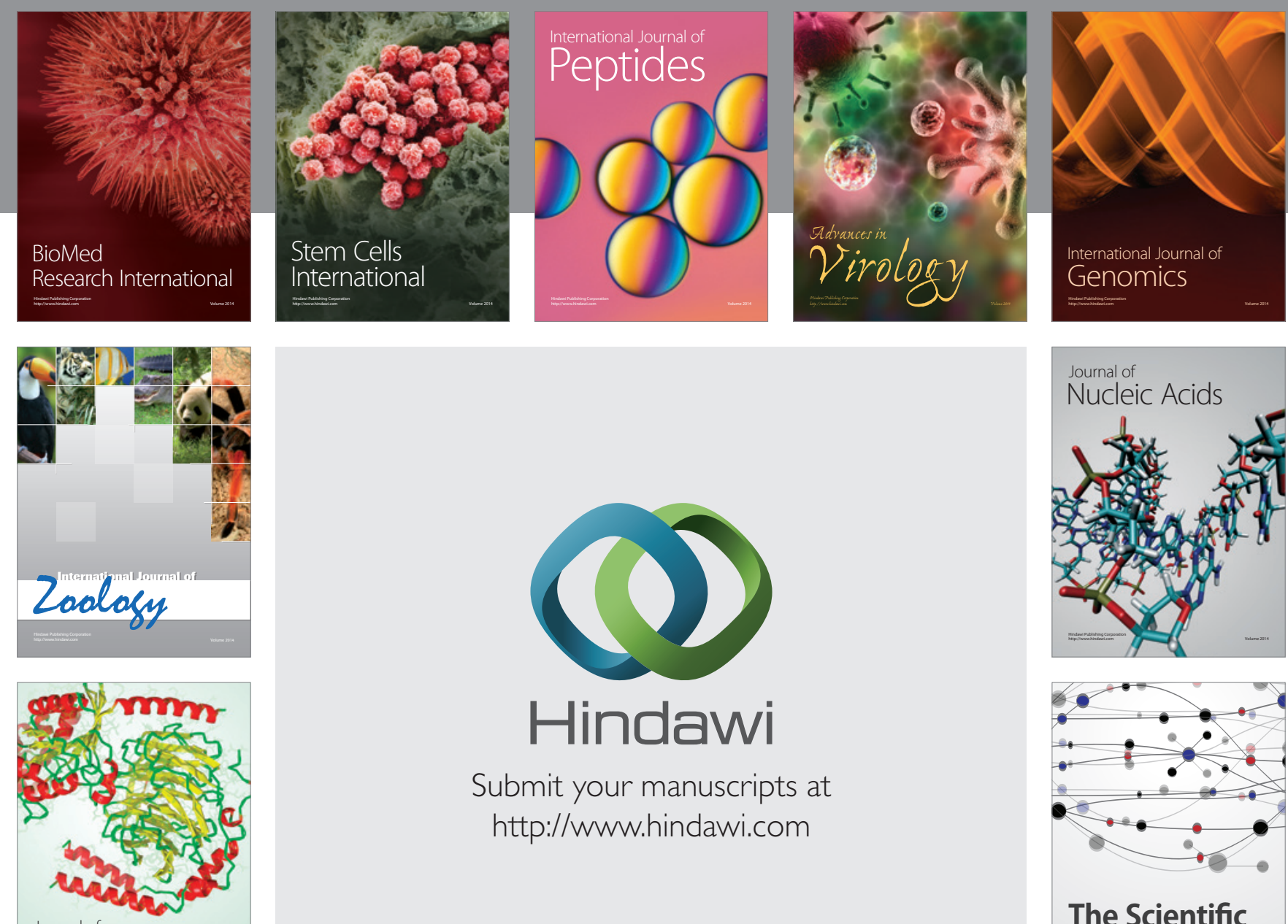

Submit your manuscripts at

http://www.hindawi.com

Journal of
Signal Transduction
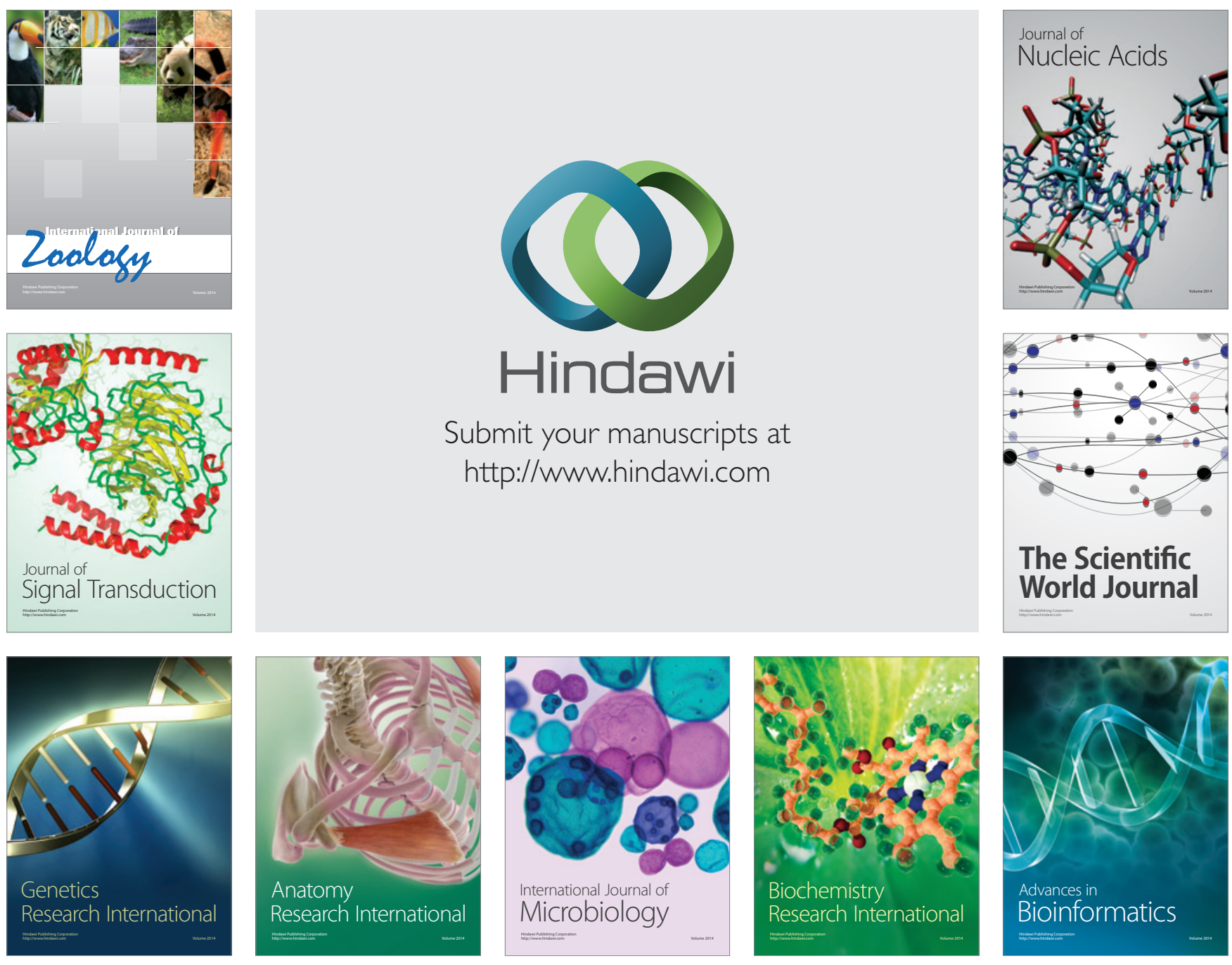

The Scientific World Journal
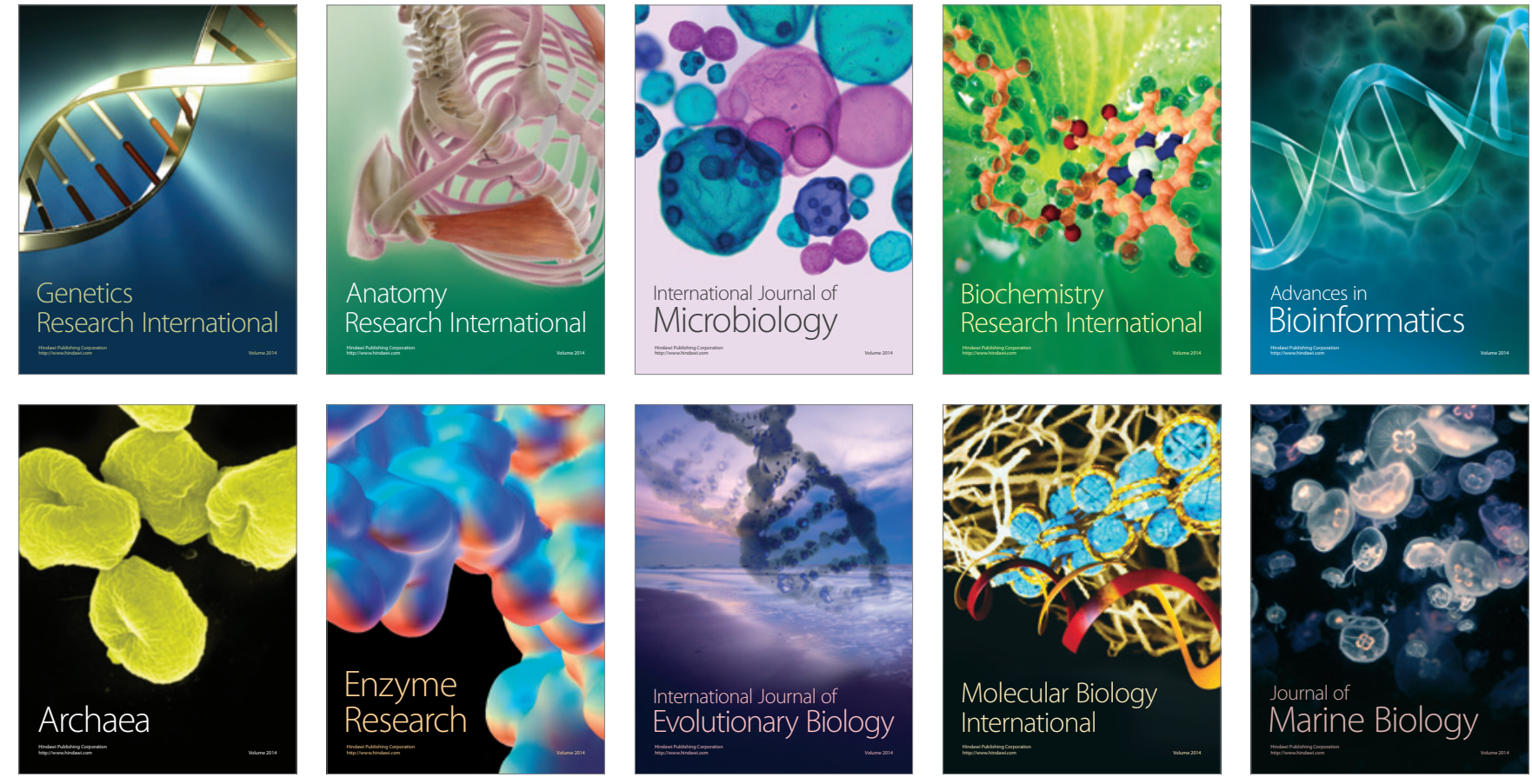